\title{
DEVELOPMENT OF HISTORICAL LEARNING MEDIA BASED ON MOBILE SMARTPHONE TO IMPROVE HISTORICAL THINKING SKILLS OF STUDENTS IN SMA NEGERI BANJARMASIN CITY
}

\author{
Muhammad Fitri \\ Master Program in History Education, Faculty of Teacher Training and Education, \\ Sebelas Maret University, Surakarta \\ e-mail: muhammadfitri@student.uns.ac.id
}

\begin{abstract}
Advances in information technology allow changes in the learning process. History is one of the important subjects at the high school level (SMA) which needs adaptation to the era of the Industrial Revolution 4.0 because historical knowledge is not only very fundamental in the formation of national identity but also a source of inspiration which is full of meaning in developing historical awareness of students. Learning history using digital can give birth to a wise generation who will be able to solve the nation's problems and make learning easier during the Covid-19 pandemic like today. However, the problem that occurs is that teachers are still not optimal in utilizing and developing digital-based historical learning media that can be accessed via each student's smartphone. This study aims to provide a historical learning innovation so that the material presented is not bored through digital media in the Industrial Revolution Era 4.0. The method used in this research is the development research method (R\&D) through the 4D model, namely Define, Design, Develop, and Disseminate. The results showed that the digitalization of historical learning in the form of developing historical learning media based on mobile smartphones made a significant contribution to making students more interested in and loving history lessons and facilitating the delivery of material during the Covid-19 pandemic as it is today to improve the historical thinking skills of students in high school. Negeri Banjarmasin City. So that history does not seem boring in the eyes of students. Based on the research results, it can be concluded that through the development of mobile smartphone-based historical learning media, history learning is more innovative in the era of the Industrial Revolution 4.0.
\end{abstract}

Keywords: Media, Historical Learning, Historical Thinking, and Banjarmasin City Senior High School

\section{Preliminary}

The development of information technology is currently developing rapidly and has a considerable influence on the life of Indonesian people and even the world. This is because almost all levels of society have a technology, one of which is a smartphone. No exception in the current world of education, there is a need for an innovation in the field of technology that can support the learning process during the Covid-19 pandemic (Coronavirus Disease), especially in historical subjects. Advances in technology allow for a change in the history learning process to be able to adapt to the times in the current era of the industrial revolution 4.0. History Learning Media that utilizes technology has a very big influence because it is considered to make all work matters easier, including learning history. By utilizing the media in learning history one of them is a mobile smartphone-based historical learning media which will certainly make it easier for teachers to teach students. 
History is described as the human past and around it which is scientifically compiled and completely encompasses the order of the facts of the period. The words history and history both refer to the chronological "development" of human life (Abbas,1997: 7). ${ }^{1}$ Meanwhile, according to another opinion, namely (Anis, 2014: 481) history is the thought and activity of humans in a time which includes anticipating problems, both as objects and as subjects when embracing their future. ${ }^{2}$

One of the lessons that can create behavior change is history learning. Because, history is a science that includes natural knowledge, research, records, and in other words includes past human activities in society and is unique. History is closely related to the identity and purpose of life to be achieved, moreover many lessons from the history of the human past are taken for the present (Pranoto, 2010: 2). ${ }^{3}$

Based on the opinions described above, in the opinion of researchers, history is a science that studies the past that happened which is associated with systematic changes in the dynamics of people's life processes.

Learning history is an important thing because historical knowledge is fundamental in the formation of national identities and is also a source of inspiration that is full of meaning in the development of historical awareness of students. Learning history has a use in the relationship of making students aware of the changes and growth of society from time to time to broaden students' views and understanding of history in obtaining, understanding, and explaining the national identity in the past to the present, and in the future. Learning history by developing and using learning media based on mobile smartphones can give birth to a wise generation who will be able to solve the nation's problems. In addition, the use of these media will improve students' historical thinking skills. Smartphone-based historical learning media is an innovative learning media that can be used according to the needs of the times and can be used by teachers and students as a support in the process of learning history during the pandemic Covid-19 or not. Currently, the mobile smartphone enthusiast is growing significantly, the World Bank reports that about 6 billion more of the world's

\footnotetext{
${ }^{1}$ Abbas, Ersis W. (1997). Memahami Sejarah. Banjarmasin: EWA Book Company.

2 Anis, M. Z. A. (2014). Sejarah Pendidikan Sejarah Dan Pendidikan Karakter Dialog Yang Tidak Pernah Tuntas (pp. 477-488).

${ }^{3}$ Pranoto, W. Suhartono. (2010). Teori dan Metodologi Sejarah. Graha Ilmu. Yogyakarta.
} 
population has used a mobile smartphone, and even a quarter of that number have it personally (Kelly \& Minges, 2012). ${ }^{4}$

In the world of education today, especially in senior high schools, many have implemented the 2013 Curriculum which is an improvement from the previous curriculum, namely the Education Unit Level Curriculum (KTSP). After the 2013 Curriculum was revised, one of the characteristics emphasized in the 2013 Revised Curriculum was the development of learning HOTS (Higher Order Thinking Skill), wherein the previous learning was only at the level LOTS (Lower Order Thinking Skill) (Mulyasa, 2018) ${ }^{5}$. In the 2013 curriculum, information technology-based learning began to be applied in Indonesia, in today's society technology has a very big influence because it is considered to be able to simplify all work matters, including learning history. Through the use of media in history learning, one of which is history learning media based on mobile smartphones, which will certainly make it easier for teachers to convey history learning material to students.

Think historically according to Wineburg (2006) explained that historical thinking begins with the act of connecting, analyzing, and applying historical concepts used in making opinions about historical concepts. Stating something about history which is based on historical facts can be categorized as historical thinking. ${ }^{6}$ Understanding historical thinking if we look carefully, learning history is not simple. Good history learning according to Garvey \& Krug (2015: 4) not limited to factual knowledge. Students are also required to understand the development of historical events imaginatively and analytically. ${ }^{7}$ In addition, according to Ofianto \& Basri (2015) said that the ability to think historically can be defined as steps or scientific processes in learning history ${ }^{8}$. Every historical thinking process always involves a thought process. Thus, historical thinking skills can also encourage its development of critical and creative thinking skills in students. The narrative about historical thinking implies a meaning about how to map the future by teaching the past. In this context, it is not correct to

\footnotetext{
${ }^{4}$ Kelly, T. dan Minges, M. (2012). Maximizing Mobile. Diakses pada tanggal 8 Mei 2021, tersedia pada situs www.web.worldbank.org

${ }^{5}$ Mulyasa. (2018). Implementasi Kurikulum 2013 Revisi (Dalam Era Revolusi Industri 4.0). Jakarta: Bumi Aksara

${ }^{6}$ Wineburg, Sam. (2006). Berfikir Historis: Memetakan Masa Depan, Mengajarkan Masa Lalu (Terjemahan). Jakarta: Yayasan Obor Indonesia.

${ }^{7}$ Garvey, Brian \& Mary Krug. (2015). Model-model Pembelajaran Sejarah Di Sekolah Menengah. Yogyakarta: Ombak.

${ }^{8}$ Ofianto dan Basri, W. (2015). Model Penilaian Kemampuan Berpikir Historis (Historical Thinking) dengan Model RASCH. Tingkap, 9(1), 67-82
} 
assume that history is a past issue that is not important to study. Historical thinking trains students to sharpen their thinking skills (Fitri, 2020). ${ }^{9}$

Until now, there have not been many studies that specifically discuss the development of mobile smartphone-based historical learning media, especially in Banjarmasin City, South Kalimantan Province. Researchers have not found a study about it, even though the media is very appropriate to be developed and used to support historical learning in the era of the Industrial Revolution 4.0 and during the current Covid-19 pandemic (2021). Therefore, this research is entitled "Development of Mobile Smartphone-Based Historical Learning Media to Improve Students' Historical Thinking Skills in State Senior High Schools in Banjarmasin City".

Based on the description above, the researcher developed a mobile smartphonebased historical learning media and researched to find out whether the historical learning media developed by the researcher was able to improve the historical thinking skills of students in SMA Negeri Banjarmasin. In addition, the results of this study are so that the media developed has the effectiveness to improve students' historical thinking skills. So that the media can be used by teachers in various schools. This research is also expected to be useful as a reference to assist readers in conducting research activities related to the development of mobile smartphone-based historical learning media to improve students' historical thinking skills.

\section{METHODS}

This research was conducted using development research or better known as R\&D (Research and Development) and using the 4D development model and using 4 stages developed by Thiagarajan (1974). ${ }^{10}$ The 4 stages, namely:1) Define, bang front-end analysis, learner analysis, task analysis, concept analysis, and specifying instructional objectives; 2) Design, bang constructing a criterion-referenced test, media selection, format selection, and initial design; 3) Develop, bang expert appraisal, and developmental testing; 4) Disseminate, bang Validation Testing, Packaging, and Diffusion and Adoption.

The research was conducted in Banjarmasin City State Senior High School which consisted of 6 XI grades and spread over 3 schools in Banjarmasin City. 3 class XI as the

${ }^{9}$ Fitri, M. (2020). Pengembangan Pembelajaran Sejarah Hots Zaman Now Melalui Model Problem Based Learning Sebagai Upaya Meningkatkan Kemampuan Berfikir Historis Peserta Didik. Pembelajaran Sejarah, 3(2), 3-5.

${ }^{10}$ Thiagarajan, S., Semmel, D. S \& Semmel, M. I. (1974). Instructional Development for Training Teachers of Exceptional Children. Minneapolis, Minnesota: Leadership Training Institute/Special Education, University of Minnesota. 
control class and 3 class XI as the experimental class with 60 students as subjects and 7 teachers. When the research was conducted in the odd semester of the academic year 2021/2022 in history subjects using the 2013 Curriculum. Researchers wrote the results by the applicable systematics.

\section{RESULTS AND DISCUSSION}

\section{Preliminary Observation Results}

Before carrying out research more specifically according to the research title, the researcher first made preliminary observations to find out how the process of learning history in the three schools was. In the first school, researchers conducted observations at SMA Negeri 6 Banjarmasin in April 2017; In the second school, researchers conducted observations at SMA Negeri 2 Banjarmasin in November 2018, and finally the third school, researchers conducted observations at SMA Negeri 7 Banjarmasin in October-November 2020 when researchers carried out the field experience program (PPL).

Based on preliminary observations at the three schools, teachers are still not optimally utilizing advances in information technology in the era of the Industrial Revolution 4.0 as a medium for learning history based on digital media. Moreover, media can be accessed by students via their respective smartphones. Digital media is a device that takes advantage of advances in information technology today. According to Flew (2008: 2-3) said that digital media is media whose content is a combination of various kinds of data such as text, voice, and images that are saved into one particular format. ${ }^{11}$

Based on observations made by researchers before the Covid-19 pandemic at SMA Negeri 6 Banjarmasin and SMA Negeri 2 Banjarmasin. Teachers tend to only use power points and blackboards as media in history learning in schools, in other words, teachers are still not optimally taking advantage of current advances in information technology by designing a mobile smartphone-based historical learning media. Meanwhile, the observations at SMA Negeri 7 Banjarmasin were carried out by researchers during the Covid-19 pandemic. However, teachers tend to only use existing digital media such as WhatsApp, Goggle Classroom, and Zoom as media used in history learning.

History learning must be able to develop critical thinking skills with various problemsolving methods. Also added by Madyarini dan Gafur (2015), which states that ideally the learning process should be fun and educate students, not just conveying subject matter to achieve exam success. In this connection, based on research Maisaroh (2011) stated that the learning process should produce students who can think critically, analytically, and creatively. ${ }^{12}$

Based on the description above, it is known that teachers tend to be less than optimal in developing a mobile smartphone-based historical learning media to support historical learning during the Covid-19 pandemic or not during the pandemic. In addition, through the development of mobile smartphone-based historical learning media, it is hoped that it can improve students' historical thinking skills.

${ }^{11}$ Flew, T. (2008). New Media: an introduction. New York: Oxford University Press.

12 Maisaroh, Siti. 2011. Upaya Peningkatan Motivasi Dan Prestasi Belajar IPS melalui Model Pembelajaran Kooperatif Tipe Teams Games Turnament. Jurnal Pendidikan Ekonomi Dinamika Pendidikan. Vol. VI, No.2. 


\section{Result of Development of Mobile Smartphone-Based History Learning Media}

By the product development model used in the development of historical learning media based on a mobile smartphone, what is meant by a mobile smartphone is a product in the form of a history learning application called "Red Coat". Therefore, the development model in this research is the 4D development model, 4 stages are passed. The stages in the implementation of the research are:

\section{Define}

In this first stage, the researcher establishes and defines the terms of development. The requirement in question is something that can show the basic need why it is necessary to develop a history learning media based on a mobile smartphone in the form of a Red Coat application at SMA Negeri Banjarmasin City. This stage is often called a needs analysis. Learning needs by analyzing the objectives and limitations of the material. Thiagarajan analyzed 5 activities carried out at the defined stage, namely:

\section{a. Front-End Analysis}

At this stage, the researcher conducted a preliminary analysis. Researchers make an initial diagnosis to increase the efficiency and effectiveness of learning. This analysis was carried out on the latest problems that occurred in these 3 schools. The problems that occur in schools are related to the media used by teachers in the history learning process with the historical thinking skills of students.

\section{b. Learner Analysis}

At this stage, the researcher analyzes the characteristics of students as the main subject in the study. Researchers conducted a characteristic analysis to determine the needs of students and these needs could be met through the development of mobile smartphonebased historical learning media. These characteristics include background academic abilities (knowledge), cognitive development of students, as well as individual or social skills related to learning topics, learning motivation, background experiences of students both as a group and as individuals. In general, students will be more interested in the material if they experience what is conveyed in the material. In addition, if the material being taught shows its benefits in the real life of students, students will be interested in learning it. One of them is the local history material of the 1945-1949 Physical Revolution in South Kalimantan which will be integrated into the media.

\section{c. Task Analysis}

At this stage, the researcher conducts a task analysis aimed at identifying the main skills that will be studied by the researcher by the current curriculum. Task analysis is the identification of skills performed by students in the teaching and learning process, especially when answering a problem or completing a task. Students will tend to feel confident when working in groups.

d. Concept Analysis

At this stage the researcher carried out a concept analysis which was carried out aimed at identifying the concepts to be taught, detailing and systematically arranging the relevant concepts to be taught based on the preliminary analysis. This analysis was carried out by identifying the material in which students had difficulty understanding it. After the 
material is selected, it is also determined which parts of the material will be the focus of development which will be integrated with the smartphone mobile media.

\section{e. Specifying Instructional Objectives}

At this stage, the researcher performs the formulation of learning objectives which is useful for summarizing the results of concept analysis and task analysis to determine the behavior of the research object. This collection of objects is the basis for compiling tests and designing historical learning media based on mobile smartphones.

\section{Design}

In this second stage, the researcher conducts a design that aims to design learning media. After defining the development, then a development prototype design is compiled by the researcher. This study develops student learning programs, namely learning steps that students must take to achieve learning goals. Thiagarajan et al divide the design into four steps that must be carried out at this stage, namely:

\section{a. Constructing Criterion-Referenced Test}

At this stage the researcher performs the construction of criteria-based tests, this test is a stage that connects the define stage with the design stage. Criteria-based tests convert the goals to be achieved in development and learning objectives that students must achieve into teaching materials. The form of this test is an assessment instrument that contains assessed aspects of the development of historical learning media based on mobile smartphones.

\section{b. Media Selection}

Media selection is carried out to identify learning media that is relevant to the characteristics of the material. More than that, the media was chosen to adjust the concept analysis and task analysis, the characteristics of the target users, and the distribution plan with the various attributes of different media. This is useful for helping students in achieving basic competencies.

\section{c. Format Selection}

The choice of format in the development of learning tools is intended to design or design learning content, selecting strategies, approaches, learning methods, and learning resources. The format chosen meets the criteria of being attractive, makes it easy, and helps in learning history.

\section{d. Initial Design}

According to Thiagarajan, et al (1974: 7) "initial design is the presenting of the essential instruction through appropriate media and in a suitable sequence." The initial design is an introduction to the subject matter of learning through appropriate media and in the appropriate order. The initial design in question is the design of all learning devices that must be done before the trial is carried out. It also includes a variety of structured learning activities such as reading texts, interviews and practicing different learning skills through 
teaching practice. In the design stage, the researcher has made a prototype or design of a mobile smartphone-based historical learning media product. ${ }^{13}$

\section{Develop}

At this stage, the researcher carried out a development that aimed to modify the prototype of a mobile smartphone-based historical learning media product which was developed by evaluating and revising before it became an effective product and could be applied in the learning process. Revisions are based on input from experts or practitioners and test result data. The steps at this stage are as follows:

\section{a. Expert Appraisal}

At this stage, expert validation is carried out by the field of learning media. Experts or practitioners' assessment of learning tools includes format, language, illustrations, and content. Based on input from experts, the learning material was revised to make it more precise, effective, easy to use, and of high technical quality.

\section{b. Developmental Testing}

Developmental testing is the activity of testing product designs on the real target subject. Development testing involves testing students' product trials for revision purposes. This development test was carried out on the research site. Product development is revised based on responses, reactions, and comments from students, teachers, and experts or observers to the learning tools that have been compiled. The results of the trial are used to improve, revise and refine the learning tools. After the product has been repaired, it is then tested again to obtain effective results. The testing - revising - retesting cycle is repeated until the development product is working consistently and effectively.

\section{Disseminate}

At this stage, the development product in the form of mobile smartphone-based historical learning media has reached the final production stage when the development test shows a positive response from experts and practitioners. After that, the product is ready to be disseminated and ready to be applied to learning in schools. Thiagarajan (1974) divides the dissemination stage into three activities, namely: validation testing, packaging, diffusion, and adoption. ${ }^{14}$

\section{a. Validation Testing}

In the validation testing stage, the mobile smartphone-based historical learning media product that has been revised at the development stage is then implemented on the real target, namely students at SMA Negeri 6 Banjarmasin, SMA Negeri 2 Banjarmasin, and SMA Negeri 7 Banjarmasin. At the time of implementation, the measurement of the achievement of the objectives was taken. This measurement is done to determine the effectiveness product developed. After the product is implemented, the developer needs to see the results of achieving the goals. The unattainable goal needs to be explained the solution so that the same mistakes do not repeat after the product is disseminated.

\footnotetext{
${ }^{13}$ Thiagarajan, S., Semmel, D. S \& Semmel, M. I. Loc. Cit.

${ }^{14}$ Ibid.
} 


\section{b. Packaging}

After going through various kinds of tests and being declared ready for use, the development product is packaged in such a way that it is ready for use in schools anytime and anywhere which can be accessed on the smartphone of each student. In this step, efforts are also made to get copyright attention and the achievement of product eligibility standards.

\section{c. Diffusion and Adoption}

The packaged development products are then distributed to schools to be adopted into legally valid learning media. In this distribution, a demonstration of the use of mobile smartphone-based learning media was also carried out. Products are distributed in high schools in the city of Banjarmasin. Especially SMA Negeri 6 Banjarmasin, SMA Negeri 2 Banjarmasin, and SMA Negeri 7 Banjarmasin.

\section{Figure 2.1 Flowchart of the 4D Development Model} By Thiagarajan

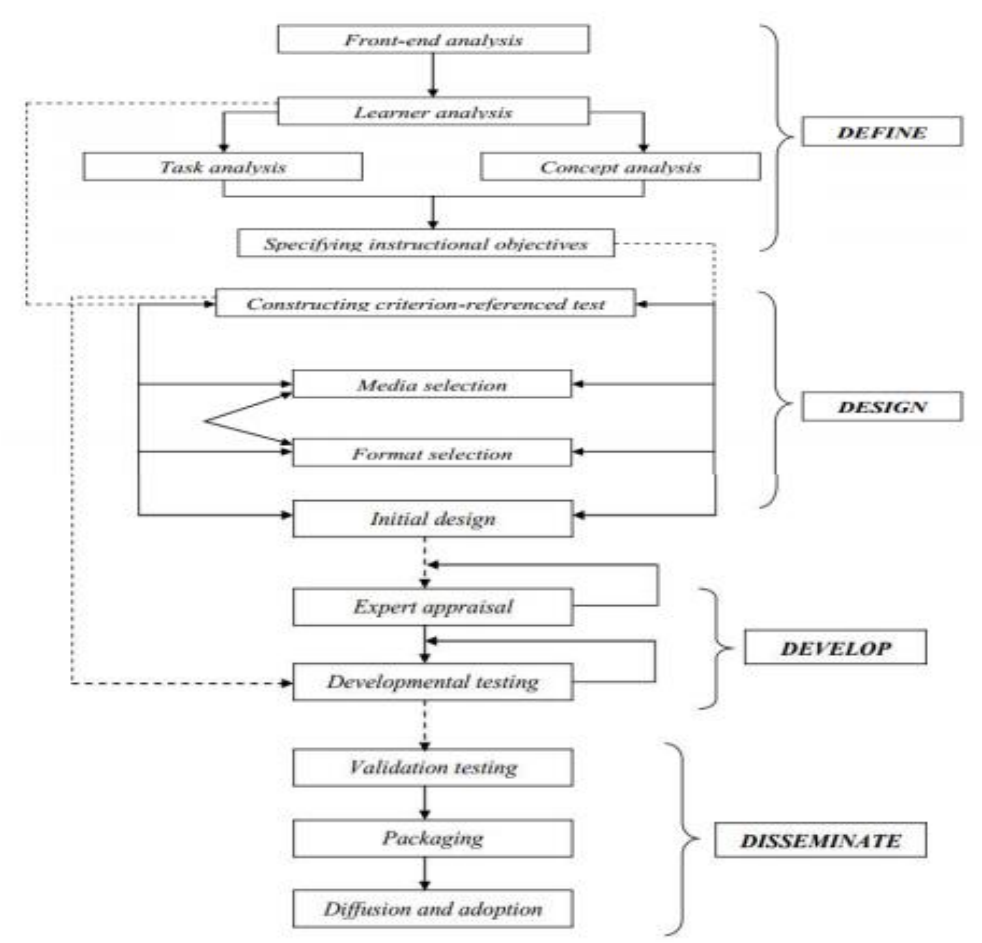

(Source : Thiagarajan, 1974)

\section{CONCLUSION}

Based on the problems and research plans described above, it is necessary to develop digital-based learning media using the 4D development model consisting of Define, Design, Develop, and Disseminate. One of them is mobile smartphone-based learning media for senior high schools in Banjarmasin City, especially SMA Negeri 6 Banjarmasin, SMA Negeri 2 Banjarmasin, and SMA Negeri 7 Banjarmasin. This is done so that history learning in schools is not boring and monotonous. In addition, media development is carried out so that 
teachers and students can take advantage of developments in information technology today, one of which is Smartphones. The media development that is carried out also has a role in the historical thinking skills of students in learning history, especially local history material that is integrated into the media.

Based on the results of the discussion and conclusions, several suggestions can be made as follows. (1) For students, it is recommended that they be able to take advantage of advances in information technology optimally as a learning medium based on mobile smartphones. The learning media is not only used in schools but can be used anywhere and anytime when students want to learn. With the use of these learning media, it is expected that students' historical thinking skills will increase more optimally. (2) For teachers of subjects, especially history subjects, it is necessary to improve skills in utilizing advances in information technology to design and develop a mobile smartphone-based historical learning media.

\section{REFERENCE}

Abbas, Ersis W. (1997). Memahami Sejarah. Banjarmasin: EWA Book Company.

Fitri, M. (2020). Pembelajaran Sejarah HOTS Zaman Now, Problem Based Learning, dan Berpikir Historis 1. Pembelajaran Sejarah, 3(2), 1-12.

Flew, T. (2008). New Media: an introduction. New York: Oxford University Press.

Garvey, Brian \& Mary Krug. (2015). Model-model Pembelajaran Sejarah Di Sekolah Menengah. Yogyakarta : Ombak.

Kelly, T. dan Minges, M. (2012). Maximizing Mobile. Diakses pada tanggal 8 Mei 2021, tersedia pada situs www.web.worldbank.org.

M.Z.Arifin Anis. (2014). Sejarah Pendidikan Sejarah Dan Pendidikan Karakter Dialog Yang Tidak Pernah Tuntas (pp. 477-488).

Madyarini \& Gafur. (2015). Komparasi Model Pembelajaran Portofolio dan BPL Terhadap Hasil Belajar IPS di SMPN Kecamatan Sewon. Jurnal Harmonisasi sosial UNY. Volume 2, No. 2.

Maisaroh, Siti. (2011). Upaya Peningkatan Motivasi Dan Prestasi Belajar IPS melalui Model Pembelajaran Kooperatif Tipe Teams Games Turnament. Jurnal Pendidikan Ekonomi Dinamika Pendidikan. Vol. VI, No.2.

Mulyasa. (2018). Implementasi Kurikulum 2013 Revisi (Dalam Era Revolusi Industri 4.0). Jakarta: Bumi Aksara.

Ofianto dan Basri, W. (2015). Model Penilaian Kemampuan Berpikir Historis (Historical Thinking) dengan Model RASCH. Tingkap, 9(1), 67-82.

Pranoto, W. Suhartono. (2010). Teori dan Metodologi Sejarah. Graha Ilmu. Yogyakarta.

Thiagarajan, S., Semmel, D. S \& Semmel, M. I. (1974). Instructional Development for Training Teachers of Exceptional Children. Minneapolis, Minnesota: Leadership Training Institute/Special Education, University of Minnesota.

Wineburg, Sam. (2006). Berfikir Historis: Memetakan Masa Depan, Mengajarkan Masa Lalu (Terjemahan). Jakarta: Yayasan Obor Indonesia. 